\title{
Assessment of Plant Growth Promoting Activities of Phosphorus Solubilizing Bacteria
}

\author{
Buddhi Charana Walpola, June-Seob Song, and Min-Ho Yoon* \\ Department of Bio-Environmental Chemistry, College of Agriculture and Life Sciences, \\ Chungnam National University, Daejeon, 305-764, Korea
}

\begin{abstract}
Plant growth promoting traits like production of indoleacetic acid (IAA), ammonia, hydrogen cyanide (HCN), siderophore, and like the enzyme activities of catalase, ACC deaminase, cellulase, chitinase and protease were assayed in vitro for twenty one phosphorus solubilizing bacteria isolated from soil isolates. Except SPP-5 and SPP-15 strains, all the other isolated strains produced IAA in various amounts of 10 to $23 \mu \mathrm{g} \mathrm{ml}^{-1}$. All strains showed positive response for ammonia production and $\mathrm{ACC}$ deaminase activity implying that they are capable of growing in a N-free basal medium. Catalase activity was found to be superiorin SPP-2, SPP-7, SPP-12 and SPP-17 compared to the other strains tested. HCN production was detected by 15 strains and among them SPP-9, SPP-15, SAph-11, and SAph-24 were found to be strong HCN producers. Except the isolates SPP-10, SPP-12, SPP-13 and SPP-14, all the other isolates produced more than $80 \%$ siderophore units. None of the strains showed cellulose and chitinase activity. SAph-8, SAPh-11, SAPh-24 and SPP-15 strains showed 35.84, 50.33, 56.64 and 34.78 U/ml protease activities, respectively. SPP-1, SPP-2, SPP-3, SPP-11, SPP-17, SPP-18, SAph-11 and SAph-24 strains showed positive response for all the tested plant growth promotion traits except cell wall degrading enzyme activities. According to the results, all the tested phosphorus solubilizing isolates could exhibit more than three or four plant growth promoting traits, which may promote plant growth directly or indirectly or synergistically. Therefore, these phosphorus solubilizing strains could be employed as bio-inoculants for agriculture soils.
\end{abstract}

Key words: Phosphorus solubilization, plant growth promoting activities, bio-inoculants

\section{Introduction}

Due to direct or indirect beneficial or detrimental activities, microbial communities are considered to be a key component of soil. They enhance the growth of plants through various processes such as decomposition, nutrient immobilization and mineralization, nitrogen fixation, denitrification, phosphorus solubilization, and etc.

Diverse groups of soil microorganisms were reported to be involved in solubilizing insoluble phosphorus complexes making them available for plants to uptake, particularly in soils with limited phosphorus supply. Microorganisms that convert insoluble phosphates into soluble forms are termed as phosphorus solubilizing microorganisms (PSMs). Their contribution is highly impressed as they supply phosphorus to plants in a more

\footnotetext{
Received : January 13. 2012 Accepted : February 3. 2012

*Corresponding author : Phone: +82428216733

E-mail: mhyoon@cnu.ac.kr
}

environmentally friendly and sustainable manner. Besides providing phosphorus to plants, PSMs also facilitate the growth of plants by stimulating the efficiency of (a) nitrogen fixation (Dobbelaere et al., 2002; Sahin et al., 2004); (b) accelerating the accessibility of other trace elements (Mittal et al., 2008); (c) ability to produce plant hormones such as auxins (Jeon et al., 2003; Egamberdiyeva, 2005), cytokinins (Garcia de Salamone et al., 2001), gibberellins (Gutierrez-Manero et al., 2001); (d) antagonism against phytopathogenic microorganisms by production of siderophores (Wani et al., 2007a), vitamin excretion (Streit et al., 1996), the synthesis of antibiotics (Lipping et al., 2008), enzymes and/or fungicidal compounds and competition with detrimental microorganisms such as chitinase, cellulose, protease (Dey et al., 2004; Lucy et al., 2004; Hamdali et al., 2008). Accordingly, these microbial communities either as single form (Poonguzhali et al., 2008; Chen et al., 2008) or in combination with other rhizosphere microbes (Zaidi and Khan, 2006; Wani et al., 2007b; 
Vikram and Hamzehzarghani, 2008) have shown substantial measurable effects on plants in conventional agronomic soils. Therefore, plant growth promoting PSMs are reported to have direct impact on soil conditions, nutrient availability and plant growth and yield.

Twenty one phosphorus solubilizing bacterial isolates which produce plant growth promotion traits, i. e. indoleacetic acid (IAA) ammonia, catalase, cellulase, protease, ACC deaminase, siderophore and hydrogen cyanide $(\mathrm{HCN})$ were evaluated in the current study in order to identify the best plant growth promoting phosphorus solubilizing strains.

\section{Materials and Methods}

\section{Isolation of strains and phosphorous solubilization}

Soil collected from Gongju-si area in Chungchugnam-do, South Korea was used in isolating phosphate solubilizing bacteria. Serially diluted soil sample aliquots were spread on to petri-dishes with National Botanical Research Institute Phosphorus (NBRIP) medium contained $10 \mathrm{~g}$ glucose, $5 \mathrm{~g} \mathrm{Ca}_{3}\left(\mathrm{PO}_{4}\right)_{2}, 5 \mathrm{~g} \mathrm{MgCl}_{2} \cdot 6 \mathrm{H}_{2} \mathrm{O}, 0.25 \mathrm{~g} \mathrm{MgSO}_{4}$. $7 \mathrm{H}_{2} \mathrm{O}, 0.2 \mathrm{~g} \mathrm{KCl}, 0.1 \mathrm{~g}\left(\mathrm{NH}_{4}\right)_{2} \mathrm{SO}_{4}$ in $1 \mathrm{~L}$ distilled water (Nautiyal, 1999). The $\mathrm{pH}$ of the media was adjusted to 7 . The plates were incubated for 7 days at $30^{\circ} \mathrm{C}$. The colonies with clear halos were considered to be phosphorus solubilizing colonies. Predominant colonies were further purified by re-streaking on the fresh NBRIP agar plates at $30^{\circ} \mathrm{C}$. Twenty one bacterial strains that exhibited large clear zones on the agar plates were selected as phosphorus solubilizing strains for further study (Fig. 1a). Selected isolates were tested for their phosphate solubilizing ability quantitatively using liquid NBRIP medium and phosphorus availability was determined according to phospho-molybdate blue color method (Murphy and Riley, 1962).

Production of indole acetic acid Bacterial strains were grown in sterilized $100 \mathrm{ml}$ liquid NBRIP media containing $1 \mathrm{ml}$ of $0.2 \%$ tryptopan and incubated for $72 \mathrm{hrs}$ with continuous shaking at $30^{\circ} \mathrm{C}$. A sterilized uninoculated medium was served as the control. Each was taken into centrifugation tube for every $24 \mathrm{hrs}$ and centrifuged $10 \mathrm{~min}$ at $12000 \mathrm{rpm}$. The clear supernatant was used to determine IAA production as described by Gutierrez et al. (2009).

Clear supernatant of $1 \mathrm{ml}$ was mixed with $4 \mathrm{ml}$ of
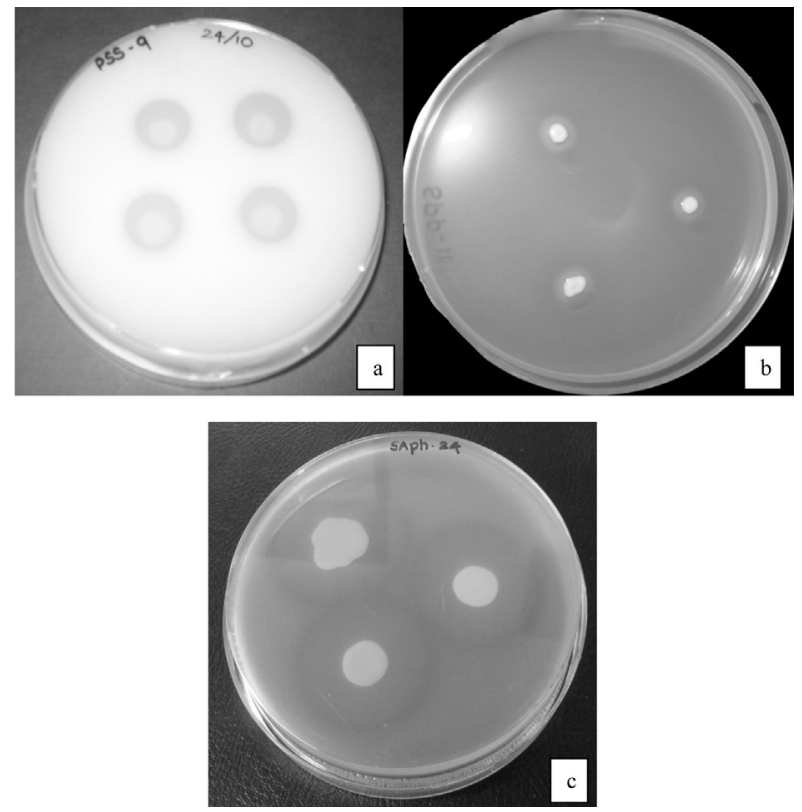

Fig. 1. Halos were produced by tested bacteria on agar plates due to (a) Phosphorus solubilization (b) Siderophore production (c) Protease activity.

the Salkowski's reagent $(50 \mathrm{ml}$ of $35 \%$ perchloric acid and $1 \mathrm{ml}$ of $0.05 \mathrm{M} \mathrm{FeCl}_{3}$ solution). The mixture was incubated in the dark at $37^{\circ} \mathrm{C}$ for 30 minutes. Development of pink color indicates IAA production and optical density was taken at $530 \mathrm{~nm}$ using UV spectrophotometer (Shimadzu-UV mini 1240). Concentration of IAA produced by cultures was measured with the help of a standard graph of IAA obtained in the range of 10 to $100 \mu \mathrm{g} \mathrm{ml}^{-1}$.

Production of ammonia The bacterial isolates were tested for the production of ammonia in peptone water. Fresh cultures were inoculated into $10 \mathrm{ml}$ peptone water and incubated for $48 \mathrm{hrs}$ at $30^{\circ} \mathrm{C}$. Nessler's reagent $(0.5 \mathrm{ml})$ was added to each tube. Development of brown to yellow color was considered to be a positive response for ammonia production (Cappucino and Sherman, 1992).

Production of hydrogen cyanide $\mathrm{HCN}$ production was tested by growing bacteria in the $10 \%$ tryptic soy agar (TSA) supplemented with glycine $\left(4.4 \mathrm{~g} \mathrm{~L}^{-1}\right)$. A filter paper soaked in picric acid and $\mathrm{Na}_{2} \mathrm{CO}_{3}(0.5 \%$ and $2 \%$ respectively) solution was fixed onto the underside of the lids of plates and incubated for 5 days at $30^{\circ} \mathrm{C}$. A change in filter paper color from yellow to orangebrown was considered to be the indication of $\mathrm{HCN}$ production (Donate-correa et al., 2004). 
Catalase activity Isolates were grown on nutrient agar media at $30^{\circ} \mathrm{C}$ for $24-48 \mathrm{hrs}$. A loopful of each culture was mixed with $50 \mu \mathrm{l}$ of $3 \%(\mathrm{v} / \mathrm{v})$ hydrogen peroxide $\left(\mathrm{H}_{2} \mathrm{O}_{2}\right)$ on a glass slide and incubated at room temperature for $1 \mathrm{~min}$ to observe the evolution of oxygen which was recorded as positive for catalase reaction (Chaiharn and Lumyong, 2009).

ACC deaminase activity Bacterial strains were assayed for 1-aminocyclopropane-1-carboxylic acid (ACC) deaminase activity by testing their ability to grow on DF minimal media (Dworkin and Foster, 1958) supplemented with $3 \mathrm{mmol} \mathrm{ACC}$ as the sole source of nitrogen (Penrose and Glick, 2003). A solid DF minimal medium containing ACC was inoculated with $10 \mu \mathrm{l}$ of starter culture (grown overnight at $30^{\circ} \mathrm{C}$ ). Plates were incubated at $30^{\circ} \mathrm{C}$ in dark and colony emergence was checked daily for upto 3 days.

Production of siderophore Siderophore production was assayed qualitatively using the chrome azurol $\mathrm{S}$ (CAS) blue agar according to Schwyn and Neilands (1987). The CAS agar was a mixture of four solutions that prepared and sterilized separately before mixing. Solution 1 (Fe-CAS indicator solution) consisted of $10 \mathrm{ml}$ of $1 \mathrm{mM} \mathrm{FeCl} \cdot 6 \mathrm{H}_{2} \mathrm{O}$ (in $10 \mathrm{mM} \mathrm{HCl}$ ), $50 \mathrm{ml}$ of an aqueous solution of CAS $\left(1.21 \mathrm{mg} \mathrm{ml}^{-1}\right)$, and $40 \mathrm{ml}$ of aqueous solution of hexadecyl-trimethylammonium bromide (HDTMA) (1.82 $\mathrm{mg} \mathrm{ml}^{-1}$ ). Solution 2 (buffer solution) was prepared by dissolving $30.24 \mathrm{~g}$ of PIPES (peperazine-N, N'-bis[2-ethanesulfonic acid]) in $750 \mathrm{ml}$ of salt solution and distilled water was added to bring the volume to $800 \mathrm{ml}$ after adjusting the $\mathrm{pH}$ to 6.8 . Agar $(15 \mathrm{~g})$ was added to this solution before autoclaving. Solution 3 was prepared by adding $2 \mathrm{~g}$ glucose and trace elements in $70 \mathrm{ml}$ distilled water. Solution 4 was $30 \mathrm{ml}$ of filter sterilized $10 \%$ casamino acid. Solution 1, 2 and 3 were autoclaved separately and after autoclaving (decrease temperature to $50^{\circ} \mathrm{C}$ ) solution 3 and 4 were added to solution. 2 Solution 1 was added last with sufficient stirring to mix the ingredients. Final mixture yielded blue to dark green color. The bacterial colonies were inoculated on the CAS agar plates. Plates were incubated at $30^{\circ} \mathrm{C}$ for $24 \mathrm{hrs}$. Orange halos around the colonies were recorded as siderophore production.

For quantitative determination of siderophore production, modified succinate medium $(1 \mathrm{~L})$ containing $4 \mathrm{~g}$ succinic acid, 6 g K $2 \mathrm{HPO}_{4}, 3$ g KH $2 \mathrm{PO}_{4}, 1 \mathrm{~g}\left(\mathrm{NH}_{4}\right)_{2} \mathrm{SO}_{4}$, $0.2 \mathrm{~g} \mathrm{MgSO}_{4} \cdot 7 \mathrm{H}_{2} \mathrm{O}$ was used to inoculate $24 \mathrm{hrs}$ old cultures of isolated strains. It was incubated for $72 \mathrm{hrs}$ with continuous shaking at $30^{\circ} \mathrm{C}$. A sterilized uninoculated medium was served as the control. Each sample was taken into centrifugation tube for every $24 \mathrm{hrs}$ and centrifuged for $10 \mathrm{~min}$ at $12000 \mathrm{rpm}$. The clear supernatant was subjected to detection of siderophore production as described by Schwyn and Neilands (1987). Quantitative estimation of siderophores was done by CAS-shuttle assay (Payne, 1994). Culture supernatant $(0.5 \mathrm{ml})$ was mixed with same amount of CAS reagent $(0.5 \mathrm{ml})$ and absorbance was measured at $630 \mathrm{~nm}$ against a reference Siderophore content in the aliquots were calculated using following formula.

$$
\% \text { Siderphore units }=\frac{\mathrm{Ar}-\mathrm{As}}{\mathrm{As}} \times 100
$$

$\mathrm{Ar}$ - Absorbance of reference

As - Absorbance of sample

Protease activity Protease activity (casein degradation) was determined using skim milk agar containing 1\% bacto tryptone, $0.5 \% \mathrm{NaCl}, 0.5 \%$ Bacto yeast extract, $1.6 \%$ agar and $1 \%$ skim milk. Plates were incubated at $30^{\circ} \mathrm{C}$ for $24 \mathrm{hrs}$. Colonies forming transparent zones, because of partial hydrolysis of milk casein, were recorded as protease producing organisms (Folasade et al., 2008).

Those organisms which produced clear zones on skim milk agar plates were sub-cultured in liquid media containing $0.7 \% \mathrm{KH}_{2} \mathrm{PO}_{4}, 0.2 \% \mathrm{~K}_{2} \mathrm{HPO}_{4}, 0.01 \% \mathrm{MgSO}_{4}$ $7 \mathrm{H}_{2} \mathrm{O}, 0.05 \%$ citric acid dehydrate, $0.1 \%$ yeast extract and $0.2 \%$ casein. They were incubated for $36 \mathrm{hrs}$ with continuous shaking at $30^{\circ} \mathrm{C}$. A sterilized uninoculated medium was served as the control. Each sample was taken into centrifugation tube for every $12 \mathrm{hrs}$ and centrifuged for $10 \mathrm{~min}$ at $12000 \mathrm{rpm}$. The clear supernatant was subjected to detection of protease activity as described by Cupp-Enyard (2008). One unit of protease activity was defined as the amount of the enzyme resulting in the release $1 \mu \mathrm{g} \mathrm{ml}^{-1}$ of tyrosine per minute under the assay conditions.

Cellulase activity The isolates were grown on CMC agar (Carboxymethyl cellulose) containing (per liter) $1 \mathrm{~g} \mathrm{KH}_{2} \mathrm{PO}_{4}, 0.5 \mathrm{~g} \mathrm{MgSO}_{4} .7 \mathrm{H}_{2} \mathrm{O}, 0.5 \mathrm{~g} \mathrm{NaCl}, 0.01 \mathrm{~g}$ $\mathrm{FeSO}_{4} \cdot 7 \mathrm{H}_{2} \mathrm{O}, 0.01 \mathrm{~g} \mathrm{MnSO}_{4} \cdot \mathrm{H}_{2} \mathrm{O}, 0.3 \mathrm{~g} \mathrm{NH}_{4} \mathrm{NO}_{3}, 10 \mathrm{~g}$ 
$\mathrm{CMC}, 12 \mathrm{~g}$ Agar. The $\mathrm{pH}$ was adjusted to 7.0 with $1 \mathrm{M}$ $\mathrm{NaOH}$. The $\mathrm{CMC}$ agar plates were incubated at $30^{\circ} \mathrm{C}$ for 5 days. At the end of incubation the agar medium was flooded with an aqueous solution of Congo red (1\%) for $15 \mathrm{~min}$ to visualize the hydrolysis zone. The Congo red solution was poured off, and the plates were further treated by flooding with $1 \mathrm{M} \mathrm{NaCl}$ for $15 \mathrm{~min}$. Colonies forming clear zone were recorded as cellulase producing organisms (Chaiharn and Lumyong, 2009).

Chitinase activity For the determination of chitinase production isolates were grown on agar plates containing $1 \mathrm{~g}$ colloidal chitin, $0.7 \mathrm{~g} \mathrm{KH}_{2} \mathrm{PO}_{4}, 0.3 \mathrm{~g} \mathrm{~K}_{2} \mathrm{HPO}_{4}$, $4 \mathrm{~g} \mathrm{NaCl}, 0.5 \mathrm{~g} \mathrm{MgSO}_{4} \cdot 7 \mathrm{H}_{2} \mathrm{O}$ and $20 \mathrm{~g}$ agar in $1 \mathrm{~L}$ (Kim et al., 2003). Plates were incubated at $30^{\circ} \mathrm{C}$ for 7 days. Colonies forming clear zone was recorded as chitinase producing organisms (Robert and Cabib, 1988).

Each of the above tests was based on two or three repeat experiments, and three replica plates per bacterium.

\section{Results and Discussion}

The phosphorus solubilizing bacteria isolated from soil demonstrated a wide range (434-667 $\mu \mathrm{g} \mathrm{ml}^{-1}$ of culture filtrate) of calcium phosphate solubilization. The bacterial isolates like SPP-1, SPP-3, SPP-5, SPP-8, SPP-9, and SPP-10 showed significantly higher amount of inorganic phosphorus solubilization, 624-667 $\mu \mathrm{g} \mathrm{ml}^{-1}$ of culture filtrate, compared to all the other bacterial strains (Table 1).

Except SPP-5 and SPP-15, all the other isolated strains produced IAA in various amounts of 10 to $23 \mu \mathrm{g}$ $\mathrm{ml}^{-1}$. On the other hand, three isolates (SPP-8, SPP-17 and SPP-18) produced remarkably high amount of IAA (more than $23 \mu \mathrm{g} \mathrm{ml}^{-1}$ ) (Fig. 2). The amount of IAA produced by some isolates was higher than reported by Banerjee et al., (2010) which ranged from 3.0 to $20.3 \mu \mathrm{g} \mathrm{ml}^{-1}$. All the isolates exhibited the highest IAA production within first 24-48 hrs followed by reduction as time progressed (Fig. 2). Among the plant growth hormones, auxin is considered to be the most effective hormone. The most common, best characterized and physiologically most active auxin is IAA, which is mainly produced by tryptophan dependent pathway by plants and many of soil microorganisms such as bacteria, fungi and algae (Sarwar and Kremer, 1995).
Table 1. Phosphorus solubilization by isolated bacterial strains.

\begin{tabular}{cc}
\hline \hline Strains & Phosphorus solubilization $(\mu \mathrm{g} / \mathrm{ml})$ \\
\hline SPP-1 & $656 \pm 5$ \\
Spp-2 & $614 \pm 3$ \\
SPP-3 & $648 \pm 4$ \\
SPP-4 & $656 \pm 9$ \\
SPP-5 & $667 \pm 4$ \\
SPP-6 & $592 \pm 6$ \\
SPP-7 & $622 \pm 5$ \\
SPP-8 & $624 \pm 9$ \\
SPP-9 & $631 \pm 14$ \\
SPP-10 & $640 \pm 4$ \\
SPP-11 & $544 \pm 9$ \\
SPP-12 & $470 \pm 8$ \\
SPP-13 & $654 \pm 7$ \\
SPP-14 & $664 \pm 11$ \\
SPP-15 & $630 \pm 2$ \\
SPP-16 & $434 \pm 3$ \\
SPP-17 & $624 \pm 3$ \\
SPP-18 & $598 \pm 15$ \\
SAph-8 & $585 \pm 3$ \\
SAph-11 & $573 \pm 5$ \\
SAph-24 & $578 \pm 9$ \\
\hline
\end{tabular}

Values given here are the means $(n=3) \pm$ standard deviation.

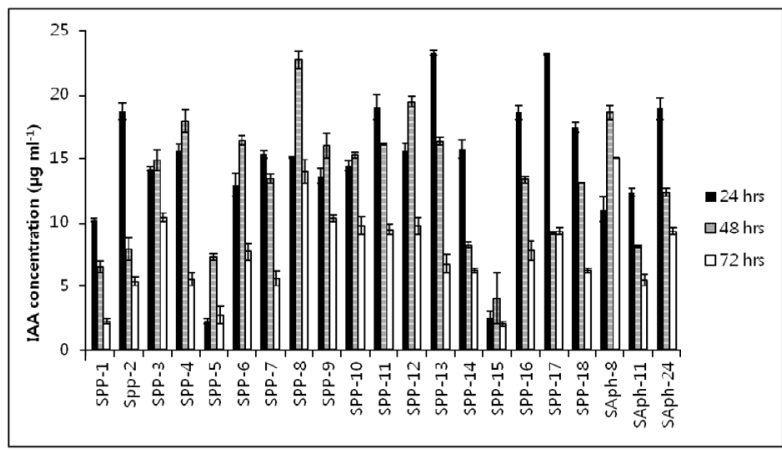

Fig. 2. IAA production of isolated phosphorus solubilizing bacterial strains.

Values given here are the means of three replicates.

IAA is known to stimulate both a rapid response (e.g. increased cell elongation) and a long-term response (e.g. cell division and differentiation) in plants (Ahmad et al., 2008). Microbial IAA production plays a significant role in the host plant's growth. IAA production in microbial strains has been investigated by several researchers (Ahmad et al., 2008; Gulati et al., 2009; Jung et al., 2011). According to the present results, 
it is apparent that most of the isolated phosphorus solubilizing strains can be considered as efficient IAA producers.

Production of ammonia is an important trait of plant growth promoting bacteria that influences plant growth indirectly (Wani et al., 2007a). Production of this secondary metabolite was found in all the studied phosphorus solubilizing isolates and SPP-13 showed the highest ammonia production followed by SPP-3, SPP-6, SPP-8, SPP-16, SAph-8, SAPh-11, and SAph-24 in the order (Table 2).

Among the studied phosphorus solubilizing isolates, 15 isolates showed $\mathrm{HCN}$ production. $\mathrm{HCN}$ is a secondary metabolite implicated in plant protection. Thus the ability to produce $\mathrm{HCN}$ is a desired quality of plant growth promoting organisms. By synthesizing $\mathrm{HCN}$, some bacteria inhibit plant disease development strengthening the host's disease resistance mechanism (Schippers et al., 1990). The presence of $\mathrm{HCN}$ in the soil can also act as an efficient biological weed control measure as it inhibits seed germination and seedling vigor (Banerjee et al., 2010). SPP-9, SPP-15, SAph-11, and SAph-24 strains were found to be strong HCN producers (Table 2).

Another important trait for plant growth promotion is siderophore production. Isolates with orange halos formed around the colonies on CAS agar were considered as siderophore producers (Fig 1b). Among them isolates SPP-5, SPP-11, SPP-15, SPP-18, SAph-8, SAph-11, and SAph-24 showed the large halos on CAS agar (Table 2). However, interestingly the isolates (SPP-4, SPP-7, SPP-8, SPP-10, SPP-12, SPP-13, SPP-14, and SPP-16) which couldn't produce halos on agar plates also showed siderophore production on liquid culture media (Fig 3). Therefore, the reliability of this halobased technique is questioned as many isolates which did not produce any visible orange halo zone on agar plates could produce siderophore. It has previously been reported that bacteria grown on CAS agar have failed to exhibit a halo, but have produced substantial concentrations of siderophore in a liquid medium that

Table 2. Response of phosphorus solubilizing bacteria to qualitative assay of plant growth promoting traits.

\begin{tabular}{|c|c|c|c|c|c|c|}
\hline Strain & Ammonia & $\mathrm{HCN}$ & Catalase & ACC deaminase & Siderophore & Protease \\
\hline SPP-1 & $+1+$ & + & +1 & + & +1 & - \\
\hline Spp-2 & $+1+$ & + & $+1+1+$ & ++ & + & - \\
\hline SPP-3 & $++1+$ & ++ & +++ & + & + & - \\
\hline SPP-4 & ++ & + & - & ++++ & - & - \\
\hline SPP-5 & ++ & - & - & +11+r & $+1+1+$ & - \\
\hline SPP-6 & $+11+$ & - & $++1+$ & + & +++ & - \\
\hline SPP-7 & ++ & - & $+1+1+$ & $+H+$ & - & - \\
\hline SPP-8 & $++1+$ & $+1+$ & ++ & $++1+$ & - & - \\
\hline SPP-9 & ++ & $+1++$ & - & ++ & + & - \\
\hline SPP-10 & + & - & - & + & - & - \\
\hline SPP-11 & + & +++ & +++ & +H+H & H11+ & - \\
\hline SPP-12 & ++ & + & $+11++$ & + & - & - \\
\hline SPP-13 & $+11+1+$ & - & H & + & - & - \\
\hline SPP-14 & ++ & - & +++ & +++ & - & - \\
\hline SPP-15 & ++ & $++1+$ & - & $+1+1+$ & $+1+1+$ & $+1+$ \\
\hline SPP-16 & $++1+$ & + & +++ & ++ & - & - \\
\hline SPP-17 & ++ & ++ & ++++ & + & $+1++$ & - \\
\hline SPP-18 & +++ & ++ & $+1++$ & +1+1+ & H11+ & - \\
\hline SAph-8 & $++1+$ & ++ & - & $+1+1+$ & $+1+1+$ & $+1+$ \\
\hline SAph-11 & $+1++$ & $+1+$ & + & $+1+1+$ & H+1+ & $+1+$ \\
\hline SAph-24 & ++++ & $+1+$ & + & H1+r & H+1+ & $+1+++$ \\
\hline
\end{tabular}

$(+)$ : Positive response [Number of $(+)$ marks express the intensity of activity]

$(-)$ : Negative response 


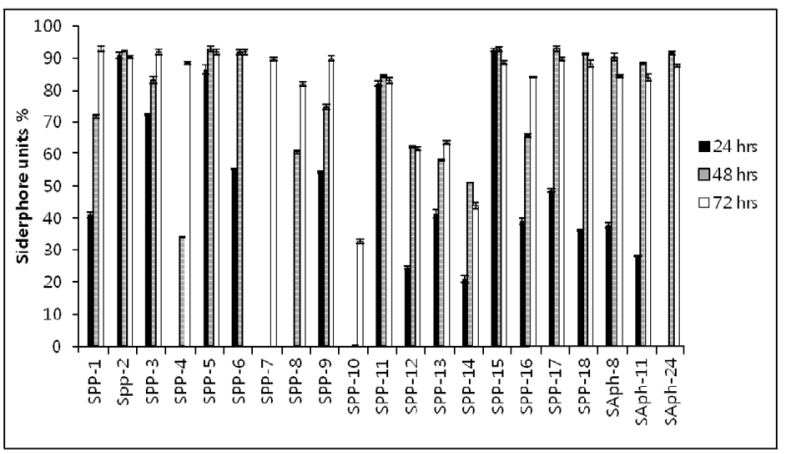

Fig. 3. Siderophore production of isolated phosphorus solubilizing bacterial strains.

Values given here are the means of three replicates.

could be measured with CAS assay solution (Alexander and Zuberer, 1991).

Most of the strains recorded the highest siderophore production within 24-48 hrs after inoculation. However, some strains (SPP-4, SAph-24, SPP-7 and SPP-8) showed delayed start of siderophore production (24-48 hrs after incubation). Except SPP-10, SPP-12, SPP-13 and SPP14 , all the other isolates produced more than $80 \%$ siderophore units. As depicted in Fig 3, it is apparent that most of the isolated phosphorus solubilizing strains can be considered as efficient siderophore producers.

Though ferric iron $\left(\mathrm{Fe}^{3+}\right)$ is the most common form of iron in nature, it is sparingly soluble. Therefore, the amount of soluble iron in the soil less supports microbial growth (Glick and Bashan, 1997) and soil microorganisms secrete siderophores-iron binding proteins to overcome this problem. It was reported that most aerobic and facultative anaerobic microorganisms produce $\mathrm{Fe}^{3+}$ chelating siderophores which bind and transport ferric iron back to the microbial cells, where it is taken up by means of cellular receptors (Bultreys et al., 2001), thus making it unavailable to the phytopathogens. Therefore, siderophore producing bacteria are good candidates for plant growth promotion especially in neutral to alkaline soil. It was found that some bacteria show antifungal activity through the production of siderophore and $\mathrm{HCN}$ or synergistic interaction of these two or with other metabolites (Ahmad et al., 2008). Several studies have demonstrated that production of siderophores, other secondary metabolites and lytic enzymes by Pseudomonas strains were most effective in controlling the plant root pathogens including $\mathrm{F}$. oxysporum and R. solani (O'Sullivan and O'Gara, 1992; Nagrajkumar et al., 2004).

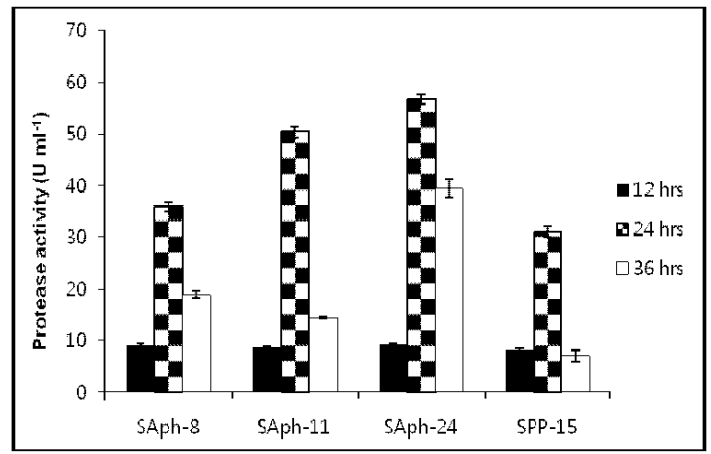

Fig. 4. Protease activity of isolated phosphorus solubilizing bacterial strains.

Values given here are the means of three replicates.

Catalase activity was detected from 15 isolates and among them SPP-2, SPP-7, SPP-12 and SPP-17 were found to exhibit the maximum activity. All isolates showed positive response for ACC deaminase activity meaning that they are capable of growing in a $\mathrm{N}$-free basal medium. ACC deaminase (1-amino cyclopropane1-carboxylic acid deaminase) is an enzyme produced by many plant growth promoting microorganisms and is involved in the stimulation of root elongation in seedlings (Lie et al., 2000). It was found that microbial IAA promotes root growth either directly by stimulating plant cell elongation or cell division or indirectly by its influence on the ACC deaminase activity.

Production of cell wall degrading enzymes was proved to be an important mechanism of fungal inhibition, thus biocontrol potential of selected phosphorus solubilizing strains was assayed in this study. None of the isolates showed cellulase and chitinase activity and only 4 isolates (SPP-15, SAph-8, SAph-11 and SAph-24) showed protease activity (Table 2). SAph-24 produced large clear zone on skim milk agar plate followed by SAph-11 (Fig 1c). Protease activity, which was detected by the estimation for each selected strain at primary screening, was confirmed by the estimation of protease activity in corresponding culture supernatants. A good correlation between the halo zone diameter of colonies grown on agar plates and the estimated level of enzyme production in liquid medium was observed. As depicted in Fig. 4 all the tested isolates showed the maximum protease production after $24 \mathrm{hrs}$ incubation.

All the above-tested phosphorus solubilizing isolates could exhibit more than three or four plant growth promoting traits, which may promote plant growth directly or indirectly or synergistically. Similar multiple 
plant growth promoting activities among plant growth promoting rhizobacteria have been reported by some other workers (Farah et al., 2006; Chaiharn and Lumyong, 2009). Several in vitro studies have also reported that the potential of phosphorus solubilizing microorganisms for the simultaneous synthesis and release of pathogensuppressing metabolites, mainly siderophore, and lytic enzymes (Pandey et al., 2006) in addition to providing phosphorus to plants.

\section{Conclusion}

According to the results, strains SPP-1, SPP-2, SPP-3, SPP-11, SPP-17, SPP-18, SAph-11 and SAph-24 also showed positive response for all the tested plant growth promotion traits except cell wall degrading enzyme activities. Interestingly the finding that all the tested phosphorus solubilizing strains showed positive response for ACC deaminase activity, ammonia, IAA and siderophore production implies their potential to be used as plant growth promoting bacterial strains. Assessment of plant growth promoting activities of phosphorus solubilizing bacteria is thus apparently helpful in producing bio-inoculants to be used as environmentally friendly approach of soil enrichment. However, field trials with selected strains would be needed to confirm the practical acceptability of the strains.

\section{References}

Ahmad, F., I. Ahmad, and M. S. Khan. 2008. Screening of free living rhizobacteria for their multiple plant growth promoting activities. Microbiol. Res. 163:173-181.

Alexander, D. B., and D. A. Zuberer. 1991. Use of chrome azurol $\mathrm{S}$ reagents to evaluate siderophore production by rhizosphere bacteria. Biol. Fertil. Soils. 12:39-45.

Banerjee, S., R. Palit, C. Sengupta, and D. Standing. 2010. Stress induced phosphate solubilization by Arthrobacter sp. and Bacillus sp. isolated from tomato rhizosphere. Aus. J. Crop Sci. 4:378-383.

Bultreys, A., I. Gheyson, H. Maraite, and E. De-Hoffman. 2001. Characterization of fluorescent and non fluorescent peptide siderophores produced by Pseudomonas syringe strains and their potential use in strain identification. App. Environ. Microbiol. 67:1718-1727.

Cappucino, J. C., and N. Sherman. 1992. Microbiolgy: A laboratory manual. Benjamin/Cummings Publishing Company, New York, pp 125-179.

Chaiharn, M. and S. Lumyong. 2009. Phosphate solubilization potential and stress tolerance of rhizobacteria from rice soil in Nothern Thailand. W. J. Microbiol. Biotechnol. 25:305-314.

Chen, Z., S. Ma, and L. L. Liu. 2008. Studies on phosphorus solubilizing activity of a strain of phospho bacteria isolated from chestnut type soil in China. Biores. Technol. 99: 6702-6707.

Cupp-Enyard, C. 2008. Sigmas's non-specific protease activity assay-Casein as a substrate. J. Vis. Exp. (19), e899, DOI: $10.3791 / 899$.

Dey, R., K. K. Pal, D. M. Bhatt, and S. M. Chauhan. 2004. Growth promotion and yield enhancement of peanut (Arachis hypogaea L.) by application of plant growthpromoting rhizobacteria. Microbiol. Res. 159:371-394.

Dobbelaere S., A. Croonenborghs, A. Thys, D. Ptacek, Y. Okon, and J. Vanderleyden. 2002. Effects of inoculation with wild type Azospirillum brasilense and A. irakense strains on development and nitrogen uptake of spring wheat and grain maize. Biol. Fertil. Soils. 36:284-297.

Donate-Correa, J., M. Leon-Barrios and R. Perez-Galdona, 2005. Screening for plant growth-promoting rhizobacteria in Chamaecytisus proliferus (tagasaste), a forage tree-shrub legume endemic to the Canary Islands. Plant Soil, 266: 261-272.

Dworkin, M. and J. Foster. 1958. Experiments with some microorganisms which utilize ethane and hydrogen. J. Bacteriol. 75:592-601.

Egamberdiyeva, D. 2005. Plant growth promoting rhizobacteria isolated from a Calcisol in a semi-arid region of Uzbekistan: biochemical characterization and effectiveness. J. Plant Nutr. Soil Sci. 168:94-99.

Farah, A., A. Iqbal, M. S. Khan. 2006. Screening of freeliving rhizospheric bacteria for their multiple plant growth promoting activity. Microbiol. Res. 63:11-19.

Folasade, M. O. and O. A. Joshua. 2008. Some properties of extracellular protease from Bacillus licheniformis Lbb1-11 isolated from 'iru', A traditionally fermented African locust bean condiment. J. Biotechnol. Biochem. 3:42-46.

Glick, B. R. and Y. Bashan. 1997. Genetic manipulation of plant growth promoting bacteria to enhance biocontrol of phytopathogens. Biotechnol. Adv. 11:353-378.

Gracia de Salamone, I. E., R. K. Hynes, and L. M. Nelson. 2001. Cytokinin production by plant growth promoting rhizobacteria and selected mutants. Can. J. Microbiol. 47: 404-411.

Gulati, A., P. Vyas, P. Rahi, and R. C. Kasana. 2009. Plant growth promoting and rhizosphere-competent Acinetobacter rhizosphaerae strain BIHB 723 from the cold deserts of the Himalayas. Curr. Microbiol. 58:371-377.

Gutierrez, C. K., G. Y. Matsui, D. E. Lincoln, and C. R. Lovell. 2009. Production of the phytohormone indole-3-acetic acid by the estuarine species of the genus Vibrio. Appl. Environ. Microbiol. 75:2253-2258.

Gutierrez-Manero, F. J., B. Ramos-Solano, A. Probanza, J. Mehouachi, F. R. Tadeo and M. Talon. 2001. The plantgrowth-promoting rhizobacteria Bacillus pumilus and Bacillus 
licheniformis produce high amounts of physiologically active gibberellins. Physiol. Plant. 111:206-211.

Hamdali, H., M. Hafidi, M. J. Virolle, and Y. Ouhdouch. 2008. Rock phosphate solubilizing Actinimycetes: Screening fro plant growth promoting activities. World J. Microbiol. Biotechnol. 24:2565-2575.

Jeon, J. S., S. S. Lee, H. Y. Kim, T. S. Ahn, and H. G. Song. 2003. Plant growth promotion in soil by some inoculated microorganisms. J. Microbiol. 41:271-276.

Jung, Y. P., K. C. Kyung, K. Y. Jang, and M. H. Yoon. 2011. Isolation and characterization of plant growth promoting rhizobacteria from waste mushroom bed from Agaricus bisporus. Korean J. Soil Sci. Fert. 44:866-871.

Kim, K. J., Y. J. Yang, and J. G. Kim. 2003. Purification and characterization of chitinase from Streptomyces sp M-20. J. Biochem. Mol. Biol. 36:185-189.

Lie, J., D. H. Ovakim, T. C. Charles, and B. R. Glick. 2000. ACC deaminase minus mutant of Enterobacter cloaca UW4 no longer promotes root elongation. Curr. Microbiol. 41: 101-105.

Lipping, Y., X. Jiatao, J. Daohong, F. Yanping, L. Guoqing, and L. Fangcan. 2008. Antifungal substances produced by Penicillium oxalicum strain PY-1-potential antibiotics against plant pathogenic fungi. World J. Microbiol. Biotechnol. 24:909-915.

Lucy, M., E. Reed, and B. R. Glick. 2004. Application of free living plant growth promoting rhizobacteria. Antonie van leeuwenhoek. 86:1-25.

Mittal, V., O. Singh, H. Nayyar, J. Kaur, and R. Tewari. 2008. Stimulatory effect of phosphate solubilizing fungal strains (Aspergillus awamori and Penicillium citrinum) on the yield of chickpea (Cicer arietinum L. cv. GPF2). Soil Biol. Biochem. 40:718-727.

Murphy, J., and J. P. Riley. 1962. A modified single solution method for the determination of phosphate in natural waters. Anal. Chem. Acta. 27:31-36.

Nagrajkumar, M., R. Bhaskaran, and R. Velazhahan. 2004. Involvement of secondary metabolites and extracellular lytic enzymes produced by Pseudomonas fluorescens in inhibition of Rhizoctonia solani, the rice sheath of blight pathogen. Microbiol. Res. 159:73-81.

Nautiyal, C. S. 1999. An efficient microbiological growth medium for screening phosphate solubilizing microorganisms. FEMS Microbiol. Lett. 170:265-270.

O' Sullivan, D. J. and F. O'Gara. 1992. Traits of fluorescent Pseudomonas spp. involved in the suppression of plant root pathogens. Microbiol. Rev. 56:662-676.

Pandey, A., P. Trivedi, B. Kumar and L. M. S. Palni. 2006. Characterization of a phosphate solubilizing and antagonistic strain of Pseudomonas putida (B0) isolated from a subalpine location in the Indian Central Himalaya. Curr. Microbiol. 53:102-107.

Payne, S. M. 1994. Detection, isolation and characterization of siderophores. In, Methods Enzymol. 235:329-344.

Penrose, D. M. and B. R. Glick. 2003. Methods for isolating and characterizing ACC deaminase containing plant growth promoting rhizobacteria. Physiol. Plant. 118:10-15.

Poonguzhali, S., M. Madhaiyan, and T. Sa. 2008. Isolation and Identification of phosphate solubilizing bacteria from chinese cabbage and their effect on growth and phosphorus utilization of plants. J. Microbiol. Biotechnol. 18:773-777.

Robert, W. K. and P. S. Cabib. 1988. Plant and bacterial chitinases differ in antifungal activity. J. Gen. Microbiol. 134:169-176.

Sahin, F., R. Cakmakci, and F. Kantar. 2004. Sugar beet and barely yields in relation to inoculation with $\mathrm{N}_{2}$ fixing and phosphate solubilizing bacteria. Plant Soil. 265:123-129.

Sawar, M. and R. J. Kremer. 1995. Enhanced suppression of plant growth through production of L-tryptophan compounds by deleterious rhizobacteria. Plant Soil. 172:261-269.

Schippers, B., A. W. Bakker, R. Bakker, and R. Van Peer. 1990. Beneficial and deleterious effects of $\mathrm{HCN}$ producing pseudomonads on rhizosphere interactions. Plant Soil. 129:75-83.

Schwyn, R. and J. B. Neilands. 1987. Universal chemical assay for detection and determination of siderophores. Anal. Biochem. 160:47-56.

Streit, F., U. Christians, H. M. Schiebel, K. L. Napoli, L. Ernst, A. Linck, B. D. Kahan, and K. F. Sewing. 1996 Sensitive and specific quantification of sirolimus (rapamycin) and its metabolites in blood of kidney graft recipients by HPLC/electrospray-mass spectrometry. Clin. Chem. 42:14171425.

Vikram, A., and H. Hamzehzarghani. 2008. Effect of phosphate solubilizing bacteria on nodulation and growth parameters of greengram (Vigna radiate L. Wilczec). Res. J. Microbiol. 3:62-72.

Wani, P. A., M. S. Khan, and A. Zaidi. 2007a Co-inoculation of nitrogen fixing and phosphate solubilizing bacteria to promote growth, yield and nutrient uptake in chickpea. Acta. Agron. Hung 55:315-323.

Wani, P. A., M. S. Khan, and A. Zaidi. 2007b. Synergistic effects of the inoculation with nitrogen fixing and phosphate solubilizing rhizobacteria on the performance of field grown chickpea. J. Plant Nutr. Soil Sci. 170:283-287.

Zaid, A., and M. S. Khan. 2006. Co-inoculation effects of phosphate solubilizing microorganisms and Glomus fasciculatum on green gram Bradyrhizobium symbiosis. Turk. J. Agric. 30:223-230 